American Journal of Economics and Business Administration 3 (4): 610-617, 2011

ISSN 1945-5488

(C) 2011 Science Publications

\title{
New Comer Orientation Training in Manufacturing Industry: A Comparison Analysis Between Indonesian Company and Japanese Company
}

\author{
${ }^{1}$ Wen-Chih Liao, ${ }^{1}$ Sulistio Handayani and ${ }^{2}$ Szu-Min Chien \\ ${ }^{1}$ Department of Business Administration, \\ National Taiwan University of Science and Technology, Taipei City 106, Taiwan \\ ${ }^{2}$ Taiwan Institute of Economic Research, \\ 7F, No.16-8, Dehuei. St., Jhongshan District, Taipei, 104, Taiwan Taipei City 104, Taiwan
}

\begin{abstract}
Problem statement: Organization must constantly expands their knowledge, skills and behavior to meet customer need and compete in today's demanding and rapidly changing business environment. As there are many foreign company in Indonesia, this research is attempt to understand how the Japanese ownership companies in Indonesia makes its new comer orientation training program differ with original Indonesian company. Approach: The research is qualitative research using case study research by interviewing General Manager and Human Resources manager in Company in Indonesia. Case study research excels at bringing us to an understanding of a complex issue or object and can extend experience or add strength to what is already known through previous research. Results: Different perspective on valuing employee and the different characteristic in the ownership of the company has given different style on its orientation training for new comer and reflected in its content of the training. Finally, new comer orientations can result in different effects. Most Japanese Company has more structures and formal orientation training for new comer than Indonesian Company. The higher the level of Japan ownership, the more the orientation are aim to provide new comer with fundamental philosophy and basic thinking of the company. They are preparing new comer to have the right attitude, knowing the basic rules and regulations. Conclusion: The contribution of this study is to gain deeper understanding from different points of views on new comer orientation training program by studying case studies in 4 companies located in Indonesia. A formal and structured new comer orientation program can reduce the turnover rate, give stability for human resources assurance and win the competition in the market. Indonesian companies will in the future trying to match with others company who's think their employee as an assets. Employee will more willing to work and contribute in the company which put employee education as an important stuff for employee because employee will able to gain more competency rather than just contributing to the company.
\end{abstract}

Key words: Orientation training, training programs, initial training, during socialization, orientation programs, reduce turnover, japanese ownership, original Indonesian, skills training

\section{INTRODUCTION}

The first initial training and development effort in the organization is orientation for new employee that informs them about the organization, the job and the people they will be working with. Orientation program can play critical role during socialization by providing new comers with a variety of important information (Anderson et al., 1996) and also considered an important psychological process that the majority of newcomers or new hires in organizations are required to go through in order to successfully adjust to their new environment.
There are some commonly cited objectives of orientation programs include the following (Feldman, 1981): reduce the newcomer's stress and anxiety, reduce startup costs, reduce turnover, reduce the time it takes for the newcomer to reach proficiency (training and break-in time), assist the newcomer in learning the organization's value, culture and expectations, assist the newcomer in acquiring appropriate role behaviors, help the newcomer adjust to the study group and its norms and encourages the development of positive attitudes.

New employee orientation programs differ from one company to the others. It is depend on the need of

Corresponding Author: Wen-Chih Liao, Department of Business Administration, National Taiwan University of Science and Technology,

Taipei City 106, Taiwan 
the orientation and company circumstances. As there are many foreign company in Indonesia, this research is attempt to understand how the Japanese ownership companies in Indonesia makes its new comer orientation training program differ with original Indonesian company.

The purpose of the research in general is to analyze the orientation program in company which located in Indonesia, model of orientation when there is Japanese ownership in the company and to analyze the difference of Japanese Ownership Company to Indonesian Company's orientation program. By doing this research hopefully a better understanding on the new comer orientation training program could be gain and more knowledge could be attained.

Literature review: As the world become internationally and force by the rapid change of organization environment, training and development is the heart of a continuous effort designed to improve employee competency and organizational performance.

Most of the new comer training programs are aim to the familiarization of the organization or for the socialization of the organization to help them adjust to the organization as soon as possible. Organizational socialization is the process by which employees learn about and adapt to new jobs, roles and the culture of the workplace (Maanen and Schein, 1979). Research indicates that socialization occurs rapidly (Bauer and Green, 1994), the resulting adjustment is relatively stable (Adkins, 1995) and early socialization experiences are related to important outcomes for both organizations and new employees (Chao et al., 1994).

Socialization tactics and strategies: Socialization is primarily a learning process (Chao et al., 1994), a process individuals learn the content necessary to fulfill their roles within an organization (Maanen and Schein, 1979). It may take new employees weeks or months to understand what is expected from them on the job and how to behave in order to be accepted by other organization members.

Understanding the most effective strategies and outcomes of the various socialization tactics may assist in creating and sustaining a competitive advantage through a productive, innovative and flexible workforce for the organization (Danielson, 2004). Maanen and Schein (1979) identified six socialization tactics used by organizations: collective-individual, formalinformal, investiture-divestiture, serial-disjunctive, sequential-random and fixed-variable. Jones (1986) grouped six dimensions into three components, namely, (1) context, (2) content and (3) a social aspect of organizational socialization tactics. Social aspect factor of socialization tactics would have the most significant and positive effect on the newcomers' affective organizational commitment.

Stage models of socialization: Many theorists who have written about organizational socialization have described the process using stage models that depict the steps or stages involved in the process. Many stage models have been proposed one of it is developed by Feldman (1981).

Anticipatory socialization: This stage occurs before new hires join the organization. Information about the organization are available from a variety or sources, such as rumors, anecdotes, advertisements, the media, through interacting with representatives of the company. During these stages, individual may be examining the extent to which their skills, abilities, needs and values match those that they perceive the organization to require or prefer.

Encounter: When new employees makes a commitment to join the organization, begin a new job, they start to learn about job tasks and receive training. During this stage, pre-employment expectation may be confirmed or rejected. New employees must manage conflicts between lifestyle and work, become familiar with the dynamics of the study group and job and lean and perform the tasks required by the job.

Change and acquisition: New employees begin to feel comfortable with their job demands and social relationships. They accept the norms and values of the group, master the tasks they must perform and resolve any role conflicts and overloads.

Content of socialization: Various tactics or strategies in socialization lead to learning of necessary content. Fisher (1986) divides the content of socialization into five categories of learning:

- Preliminary learning-including the discovery that learning will be necessary, what to learn and whom to learn from

- Learning about the organization-including the goals, values and policies of the organization

- Learning to function in the study group-including the values, norms, roles and friendships within the group

- Learning how to perform the job-including the necessary skills and knowledge for a particular job

- Personal learning-learning from experience with the job and organization, including self identity, expectation, self-image and motivation 
Table 1: Socialization content

\begin{tabular}{ll}
$\begin{array}{l}\text { Performance proficiency } \\
\text { People }\end{array}$ & $\begin{array}{l}\text { Learning and mastering the knowledge, skills and abilities to perform the required work task. } \\
\text { Establishing successful and satisfying work relationships with organizational members. } \\
\begin{array}{l}\text { Language } \\
\text { organization. }\end{array} \\
\begin{array}{l}\text { Organizational } \\
\text { goals and values }\end{array} \\
\text { Understanding the profession"s technical language as well as acronyms, slang and jargon unique to the } \\
\text { History }\end{array}$ \\
$\begin{array}{l}\text { Understanding the rules or principles that maintain the integrity of the organization. } \\
\text { Source: Chao } \text { et al. (1994) }\end{array}$ & Learning the organization"s traditions, customs, myths, personal background of other members \\
\hline
\end{tabular}

Those categories showed that the content of what newcomers learn or what organizations expect them to learn is not one-dimensional but covers multiple aspects.

Specifically, Chao et al. (1994) analyzed the content of socialization and developed the multidimensional measures of socialization that subsume the following six components. See Table 1. Haueter et al. (2003) found multi-items measure be grouped into three components, namely, (1) organization, (2) task and (3) group dimensions.

New comer orientation: Most organizations use formal orientation program as part of socialization process (Saks and Ashforth, 1997). Mentorship is another important tool for promoting newcomers' adjustments and retention during socialization processes (Bozionelos, 2006). The length of the orientation programs varies, from few hours to several days to periodic sessions scheduled over several months.

Psychological contract during socialization: Psychological contract are defined as the beliefs individual hold regarding the terms and condition of the exchange agreement between themselves and their organizations (Rousseau, 1989). A study by Robinson et al. (1994) found that new comer change their psychological contract perceptions based on the reality they encounter after entry. The period of organizational entry and socialization is characterized by sense making processes through which newcomers come to understand, interpret and respond to their new environmen. The description of sense making as a process through which newcomers actively form and change their cognitive schemas makes it relevant to apply this to psychological contract formation (Vos et al., 2003).

Vos et al. (2003) have support the idea that during the socialization process newcomers actively make sense of promises based on their interpretations of experiences encountered. The research also suggest that the first months after entry are important for employers to "set the stage" for what newcomers can realistically expect, Thus employers should not postpone the exchange of information about their inducements to a later stage of the employment relationship because at that time employees might have become less flexible in adapting their initial expectations.

\section{METERALS AND METHODS}

Research methodology: The research is qualitative research using case study research by interviewing General Manager and Human Resources manager in three Japanese Subsidiaries Company and general manager in one original Indonesian company in Indonesia. Case study research excels at bringing us to an understanding of a complex issue or object and can extend experience or add strength to what is already known through previous research. Six steps were used:

- Determine and define the research questions

- Select the cases and determine data gathering and analysis techniques

- $\quad$ Prepare to collect the data

- Collect data in the field

- Evaluate and analyze the data

- $\quad$ Prepare the report

Interviews were carried out in a private room and lasted for around an hour to an hour and a half. It is conduct in Indonesian. Tape recordings of each interview were made. Notes were also taken during the interview and after each interview; a summary of each interview was drafted.

The interviewer is attempting to conduct these interviews shortly after conversations of interest, while the interview will be formal and structured. The general strategy for the interviews is to start off with broad questions and follow up on the interviewee's responses, to capture her or his meanings and to avoid imposing my meanings on the interviewee. The result of the interview will be analyze try to found whether different level of stockholder will have different scenario of the orientation program. The name of the company will be symbolized to keep the confidentiality of the organization.

For the purpose of this comparison, two major manufacturing company owned by $100 \%$ Japanese company are taken and one 50-50\% owned by Japanese and Indonesian company and one locally owned assembling companies are taken as examples-J1 Corporation, J2, Corporation, JI Corporation and I Corporation. Ownership of the above organizations is as summarized in Table 2. 
Am. J. of Economics and Business Administration 3 (4): 610-617, 2011

Table 2: Ownership structure and scale of the company

\begin{tabular}{llr}
\hline Name of organization & Ownership (\%) & Number of Employees (Staff and Worker, 2009) \\
\hline J1 Corporation & 100 Japanese Company & 4,000 \\
J2 Corporation & 100 Japanese Company & 7,000 \\
JI Corporation & 50 Japanese 50 Indonesian & 5,000 \\
I Corporation & 100 Indonesian & 13,000 \\
\hline
\end{tabular}

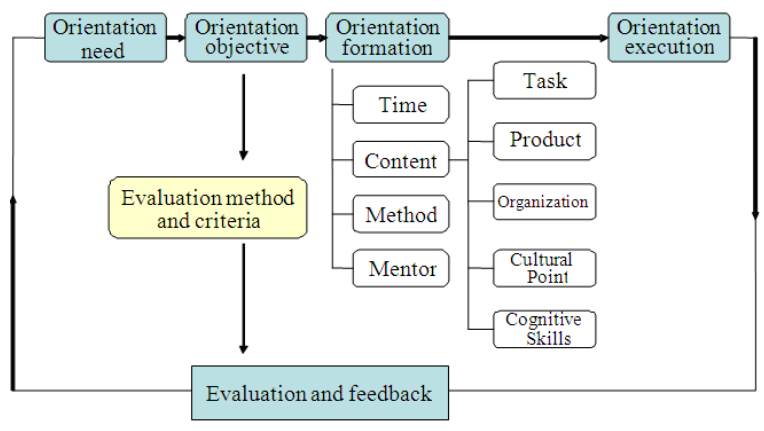

Fig. 1: Research framework

All the companies chosen as the object in this research are classified as large companies in Indonesia based on their capital and number of workers. The ability of the company to provide the orientation is merely not because of the financial situation rather more to the company's philosophy on its employee.

The interviewees for data collection in this study are a key person in the organization where the data collection being held. Their competencies and capabilities are unquestionable as they are person whose are professional in their field. Though they have various backgrounds of studies, they already stay in the company for more than 5 years and their experiences in human resources field are already more than 3 years.

Research question: Interview questions are structured based on the following concept and ideas:

- Question related to the content of the socialization referring to Fisher (1986) and Haueter et al. (2003) founding

- Question related to company expectation to the newly hired employee such as jump-starting their productivity (Rollag et al., 2005), producing behaviors consistent with corporate goals resulting in outcomes that support the needs and objectives of the organization (Baker and Feldman, 1991)

- Question related to objective of the orientation program, to reduce the newcomer's stress and anxiety, reduce start up costs, reduce turnover (Feldman, 1981), ensure the continuity of central values and norm, assist in creating and sustaining a competitive advantage through a productive, innovative and flexible workforce (Danielson, 2004)
- Question related to the Evaluation of the orientation

Interview Question is as follows:

- Do you have any orientation program?

- Why orientation program is needed?

- What is the objective of the orientation program?

- What is the content of the orientation program?

- How they deliver the program?

- What is their thinking when making the orientation program?

- How Japanese headquarter influence the making of orientation program?

- How they do their evaluation?

Research framework: There is some term which related to new comer orientation training. These terms are a factor which involve in the process of the orientation training see Fig. 1.

Orientation need: "How company thinks the importance of having orientation for new comer".

Orientation objective: "The Company goal in providing orientation for new comers".

Orientation formation: "Factors need to be concern in forming the orientation".

Time: "When and how long the new comer orientation training will be held".

Method: "How to deliver the new comer orientation training program".

Mentor: "Who is going to deliver the new comer orientation training program".

Content: "Issues, topic covers in the orientation training program".

Orientation execution: "The day when the orientation being executed".

Evaluation method: "How the successes of the orientation will be measure". 


\section{RESULTS}

Orientation In $100 \%$ Indonesian company: Indonesian company merely has no structured, formal orientation training for new employee see Table 2. New comer are demanded to prepare their self, learn about the company and job related function by doing the job. When new employee come to company on the first day, a person in the division usually a supervisor whom new comer are going to work with, will lead him / her to know a glance about the company's general rules.
Company tour is held for about 2-3 $\mathrm{h}$ depending on individual case.

There are no specific human resources division in this company to held human resources activity such as recruitment process, training. The manager argues "if we can make it simple why we need to make it complicated". Having specific human resources division is not yet necessary in this company. I Company have probationary period for new employee, the period is last for three month.

Table 2: Summary of new comer orientation program

\begin{tabular}{|c|c|c|c|c|}
\hline Code & $\mathrm{J} 1$ & $\mathrm{~J} 2$ & $\mathrm{JI}$ & $\mathrm{I}$ \\
\hline Ownership & $100 \%$ Japanese & 100\% Japanese & $\begin{array}{l}50 \% \text { Japanese } \\
50 \% \text { Indonesian }\end{array}$ & $100 \%$ Indonesian \\
\hline Type & Formal & Formal & Formal & Informal \\
\hline \multirow[t]{4}{*}{ Organization } & $\begin{array}{l}\text { Introduction-word from the HR, } \\
\text { introduction of people }\end{array}$ & $\begin{array}{l}\text { Opening and introducing } \\
\text { among participants }\end{array}$ & & \\
\hline & Company profile & Company profile & Company profile & Company profile \\
\hline & Company culture & $\begin{array}{l}\text { Company culture } \\
\text { Organizational Structure } \\
\text { and emergency plans } \\
\text { Company song }\end{array}$ & & \\
\hline & Company regulation & $\begin{array}{l}\text { Policies, rules and } \\
\text { company disciplines }\end{array}$ & $\begin{array}{l}\text { Company policies, } \\
\text { rules and disciplines }\end{array}$ & Company regulation \\
\hline \multirow[t]{2}{*}{$\begin{array}{l}\text { Work safety, } \\
\text { system and rules }\end{array}$} & & System and rules & & System and rules \\
\hline & & Labor union & & \\
\hline Cognitive skills & & Fundamental leadership & Leadership & \\
\hline \multirow[t]{3}{*}{ Cultural points } & Right mental attitudes & Positive mental attitudes & & \\
\hline & $5 \mathrm{~K} / \mathrm{S} / \mathrm{R}$ (theories) & $5 \mathrm{~K} / \mathrm{S} / \mathrm{R}$ (theories) & KAIZEN (Outside training centre) & \\
\hline & $\begin{array}{l}\text { Product inspection and } \\
\text { energy saving principles } \\
\text { Global principle of the company } \\
\text { Basic Business philosophy } \\
\text { Production security } \\
\text { management, information security }\end{array}$ & Ethics, cost saving, go green & & \\
\hline \multirow[t]{5}{*}{ Product } & Product Knowledge & Product Knowledge & Product Knowledge & \\
\hline & Process Knowledge (Plant tour) & $\begin{array}{l}\text { Process flow introduction } \\
\text { Plant tour }\end{array}$ & Process flow & \\
\hline & Basic quality, ISO 9001 & $\begin{array}{l}\text { ISO } 9001 \text { and ISO TS } \\
16949 \text { introduction }\end{array}$ & & \\
\hline & ISO14001 & ISO14001 introduction & & \\
\hline & Quality control circle & $\begin{array}{l}\text { Quality control circle } \\
\text { (theories) and simulation }\end{array}$ & & \\
\hline \multirow[t]{5}{*}{ Task } & & Customer satisfaction & Customer satisfaction & \\
\hline & & Job description & Finance and adult & \\
\hline & & & IT-system-and General affairs & \\
\hline & & & Risk management & \\
\hline & & & Human Resources & \\
\hline Evaluation & Paper based test & Paper based test & Paper based test & No evaluation \\
\hline Period & 3 days & 5 days & 5 days & 1 day \\
\hline Mentor & In house training & In house training & In house training & In house training \\
\hline $\begin{array}{l}\text { Min number } \\
\text { of participant }\end{array}$ & 10 persons & 10 persons & 30 persons & \\
\hline Major content & Cultural point and product & Organization and product & Task and KAIZEN & Job related task \\
\hline Others & & $\begin{array}{l}\text { Probationary period } \\
3 \text { months }(\mathrm{OJT})\end{array}$ & OJT & $\begin{array}{l}\text { Probationary } \\
\text { period (OJT) }\end{array}$ \\
\hline Objectives & $\begin{array}{l}\text { To prepare new comer with } \\
\text { sufficient knowledge and able } \\
\text { to work with the right mental } \\
\text { attitude }\end{array}$ & $\begin{array}{l}\text { To provide and increase a } \\
\text { high quality, skilled and } \\
\text { competent workers, } \\
\text { especially to increase } \\
\text { positive mental attitudes } \\
\text { among company personals. }\end{array}$ & $\begin{array}{l}\text { To equip new comer with } \\
\text { sufficient knowledge of every } \\
\text { divisions in the company. } \\
\text { To enhance the quality of } \\
\text { decisions making the future. }\end{array}$ & $\begin{array}{l}\text { The companies are looking for } \\
\text { people who ready to make } \\
\text { contribution for the company, } \\
\text { learning about the company and } \\
\text { its process by doing their job } \\
\text { during on job training is the } \\
\text { most effective way to apply in } \\
\text { the company, new comer }\end{array}$ \\
\hline
\end{tabular}

Orientation program is not yet necessary in this company. Degree of influence from headquarter in Japan. A guidance was given to the company from headquarter in Japan to hold orientation training for new comer, the designation in made independently by the HR division Japanese Company influence at the early stage during company development, now independently held by HR division no influence from headquarter in Japan. Training design and provided by HR division based on company vision and goals none 
I Company prefer employee to have his or her own experience to know and learn about the company. The sense making process which leads to psychological contract are depends on individual which cause differences among employee. There are no efforts from the company to interfere the sense making process of the employee formally. Employee are not consider as an asset in I company.

Orientation in $100 \%$ Japanese ownership company: A formal and structure new comer orientation training are given for new comer in $100 \%$ Japanese company in Indonesia. The objective of J1 company wish to prepare new comer with sufficient knowledge and able to work with the right mental attitude while $\mathrm{J} 2$ company want to provide and increase a high quality, skilled and competent workers, especially to increase positive mental attitudes among company personals see Table 2. $\mathrm{J} 1$ head quarter have guideline and is applied to every $\mathrm{J} 1$ company worldwide. Human resources division in $\mathbf{J} 2$ company are independently set and designed the new comer orientation training program and others training program provided to employee in the company.

The whole program of $\mathrm{J} 1$ and $\mathrm{J} 2$ is executed in house and the mentor of the program are human resources staff. Content of the new comer orientation programs are categorized into five and explain as below.

Organization: Japanese company wish its employee to have certain basic knowledge and information of the organization as a basic thinking and guide in doing their job in the future. Knowing the information of the organization able to tighten the psychological contract and gained employee engagement. The more degree of Japanese ownership the more they give new employee appropriate information about the company.

Cultural point: All the Japanese company are applying famous Japanese companies way of thinking and value. The Global principle and basic business philosophy given in $\mathrm{J} 1$ orientation program is due to harmonize all the idea, principles and rules in the subsidiaries companies and to make an integration between all the subsidiaries in all over the world.

Product: Content of the knowing product section are including product name, specification, highlight product, process flow and material. They will have a plant tour in the factory lead by the head of the factory. New comer might have different job function in the future, by knowing the product, the process and all important things on the product, the integration will be gain thoroughly.
Cognitive skills: Cognitive skills mean an ability to learn and make sense of new information. An additional cognitive skills training is given in J2. A leadership training to prepare new comer with the ability to decide the right things and things right in performing their jobs. Leadership training is not given in $\mathrm{J} 1$ as it is consider not necessary for new employee level. All production in $\mathrm{J} 1$ Company is aim to satisfied foreign market, none of $\mathrm{J} 1$ 's product is sold in Indonesian market.

Job related task: Information on job description is given in $\mathrm{J} 2$ to make new comer understand clearly about the scope of the work and understand the relation of one position to the others. By treating all division as customer, J1 Company is trying to reach customer satisfaction at the end.

Evaluation method: The method of the evaluation is a written or essay questions. In J2 and JI Company, there is a minimum score need to be obtain in order to pass the orientation training otherwise the recruitment process will be cancel and classified as not qualified to job vacancy. From the research, the obstacles in doing evaluation, new comer do not really understand the content and the meaning of the orientation.

Japanese joint venture $\mathbf{5 0 \%}$ Indonesian and $\mathbf{5 0 \%}$ Japanese ownership): JI has most frequent orientation training programs per year comparing with others in the research as its market share is huge but there is no influence from the Japan mother company. It is formed, structured and held in the headquarters and in every subsidiaries office all over Indonesia. Before holding orientation training, new comer will wait in the designate work place and have On-The Job training program. The length of the program varies based on company's need and objective at certain time. JI give a complete set of job division lecture. New comers are being rotate to several divisions during their first year. Every employee are expected to have a leadership skills, but in order to maintain the Japanese company value, company gives Kaizen training program.

\section{DISCUSSION}

Comparison of Indonesian and Japanese ownership: Most Japanese Company has more structures and formal orientation training for new comer than Indonesian Company. The higher the level of Japan ownership, the more the orientation are aim to provide new comer with fundamental philosophy and basic thinking of the company. Indonesian company is still very traditional. They expect new comer to make senses of the company culture, rules and regulation by their self. 
Japanese company are emphasizing on behavior and mental attitude while Indonesian company are focusing on get all the jobs done. Japanese company trains their people to be generalist, people who knowledgeable about many department and colleagues while Indonesian company train their employee to be specialist, people who knowledgeable about certain domain.

As Japanese company thought its worker as an asset, they have broader and longer view in preparing their worker to be ready and contribute for the company. Indonesian company thinks an employee as tools in order to gain the organization goal and objective in general which is market share and high profit. They do not see yet any necessary point to hold an orientation training program for new comer. It is not important for Indonesian company whether the worker feels welcome and be a part of the company.

\section{Boundaries in new comer orientation training program:}

- Too much information in times. As an impact they just memorize not understanding it carefully

- The communication is one way communication, no interaction between mentor and participants during orientation programs

- Once the program being evaluated, training will be end

- It is difficult to judge the effectiveness of the orientation training for new comer, especially when it is concern with worker individual effort

\section{CONCLUSION}

Japanese company trying to ensure the continuity of central values and norm, assist in creating and sustaining a competitive advantage through a productive, innovative and flexible workforce. This is in accordance with the research by Danielson (2004). Japanese company used new comer orientation days as an opportunity to show their strong commitment to the well-being and development of the company's workforce, they trying to tied and make a connection which lead to good psychological contract between company and employee.

Japanese company trying to prepare and increase high quality worker by giving the fundamental knowledge and information. New comers with behaviors consistent with corporate goals can support the needs and objectives of the organization which match with Baker and Feldman (1991) founding. JI Company wants to equip new comer with sufficient knowledge of work task in every division in the company because they focus on the competency of the employee, think employee as in between of assets and tools of the company to achieve the goal.

Based on the research finding, a formal and structured new comer orientation program is necessary to be held in the company. The complete information need to be assure being transfer to the new comers to gain a mutual understanding and making new worker to feel an acceptance and welcome by the company will increase their commitment to the company.

As Indonesian economic is getting stronger, employment market will also get an impact and many job vacancies are being offer in the future. Employee are more willing to work and contribute in the company which put employee education as an important stuff because employee will able to gain more competency rather than just contributing to the company.

Other reason that make new comer orientation is necessary is that core value, company philosophy, regulation and procedure are become more important in the future. Without knowing the basic philosophy, value, the decision making could possibly incoherence with the company goal overall thus could lead to wrong decision making.

The new comer orientation training program could give stability for human resources assurance in the company. Indonesian companies will in the future be trying to match with others company who's think their employee as an assets.

The limitations of the research is the object of the research are limited to four different company, thus it not a reflection of the entire industry.

\section{REFERENCES}

Adkins, C.L., 1995. Previous work experience and organizational socialization. Acad. Manage. J., 38: 839-862.

Anderson, N.R., N.A. Cunningham-Snell and J. Hiagh, 1996. Induction training as socialization: Current practice and attitudes to evaluation in British organizations. Int. J. Selection Assessment, 4: 169183. DOI: 10.1111/j.1468-2389.1996.tb00052.x

Baker, H.E. and D.C. Feldman, 1991. Linking organizational socialization tactics with corporate human resource management strategies. Hum. Resource Manage. Rev., 1: 193-202. DOI: 10.1016/1053-4822(91)90014-4

Bauer, T.N. and S.G. Green, 1994. Effect of newcomer involvement in work-related activities: A longitudinal study of socialization. J. Applied Psychol., 79: 211-223. DOI: 10.1037/00219010.79.2.211 
Bozionelos, N., 2006. Mentoring and expressive network resources: Their relationship with career success and emotional exhaustion among Hellenes employees involved in emotion work. Inter. J. Hum. Resource Manage., 17: 362-379. DOI: 10.1080/09585190500405009

Chao, G.T., A.M. O'Leary-Kelly, S. Wolf, H.J. Klein and P.D. Gardner, 1994. Organizational Socialization: Its content and consequences. J. Applied Psychol., 79: 730-743. DOI: 10.1037/0021-9010.79.5.730

Danielson, M.M., 2004. A theory of continuous socialization for organizational renewal. Hum. Resource Dev. Rev., 3: 354-384. DOI: 10.1177/1534484304271528

Feldman, D.C., 1981. The multiple socialization of organization members. Acad. Manage. Rev., 6: 309-318. DOI: $10.2307 / 257888$

Fisher, C.D., 1986. Organizational socialization: An integrative view. Res. Personnel Hum. Resource Manage. Rev., 4: 101-145.

Haueter, J.A., T.H. Macan and J. Winter, 2003. Measurement of newcomer socialization: Construct validation of a multidimensional scale. J. Vocat. Behav., 63: 20-39. DOI: 10.1016/S00018791(02)00017-9
Jones, G.R., 1986. Socialization tactics, self-efficacy and newcomers' adjustments to organizations. Acad. Manage. J., 29: 262-279.

Maanen, J.V. and E. Schein, 1979. Toward a theory of organizational socialization. Res. Organiz. Behav., 1: 209-264.

Robinson, S.L., M.S. Kraatz and D.M. Rousseau, 1994. Changing obligations and the psychological contract: A longitudinal study. Acad. Manage. J., 37: 137-152.

Rollag, K., S. Parise and R. Cross, 2005. Getting new hires up to speed quickly. MIT Sloan Manage. Rev., 46: 35-41.

Rousseau, D.M., 1989. Psychological and implied contracts in organizations. Employee Responsibilities Rights J., 2: 121-139. DOI: 10.1007/BF01384942

Saks, A.M. and B.E. Ashforth, 1997. A longitudinal investigation of the relationships between job information sources, applicant perceptions of fit and work outcomes. Personnel Psychol., 50: 395426. DOI: 10.1111/j.1744-6570.1997.tb00913.x

Vos, A.D., D. Buyens and R. Schalk, 2003. Psychological contract development during organizational socialization: adaptation to reality and the role of reciprocity. J. Organ. Behav., 24: 537-59. DOI: 10.1002/job.205 